\title{
A review of plant protection against the olive fly (Bactrocera oleae (Rossi, 1790) Gmelin) and molecular methods to monitor the insecticide resistance alleles
}

\author{
Matjaž HLADNIK ${ }^{1}$
}

Received October 27, 2016; accepted Janury 17, 2017.

Delo je prispelo 27. oktobra 2016, sprejeto 17. januarja 2017.

\begin{abstract}
Olive fly (Bactrocera oleae (Rossi, 1790) Gmelin) is one of the most important olive pests worldwide. Most plant protection measures are based on insecticides, especially organophosphates, pyrethroids, and recently a spinosad. Insecticides are used as cover sprays or in more environmentally friendly methods in which insecticides are used in combination with attractants and pheromones as bait sprays or for mass trapping. However, due to negative impacts of insecticides to environment, new plant protection methods are constantly developing with the aim to lower the consumption of insecticides or even to eliminate them by biological control with entomopathogenic organisms, sterile insect technique (SIT), or transgenic method RIDL (release of insects carrying a dominant lethal). However, these methods need to be improved in order to guarantee adequate protection. Alternative methods than those traditionally used are required due to long term usage causing the development of resistance to the insecticides, ultimately lowering their effectiveness. Molecular methods for monitoring the frequencies of resistant alleles and the current status of resistance alleles in olive growing countries are reviewed here.
\end{abstract}

Key words: organophosphates; ace gene; resistance alleles; plant protection methods; alternative methods; spinosad; biological control

\author{
IZVLEČEK \\ PREGLED VARSTVA PRED OLJČNO MUHO \\ (Bactrocera oleae (Rossi, 1790) Gmelin) IN \\ MOLEKULARNIH METOD ZA SPREMLJANJE \\ ALELOV, ODGOVORNIH ZA RAZVOJ ODPORNOSTI \\ NA INSEKTICIDE
}

Oljčna muha (Bactrocera oleae) je eden najpomembnejših svetovno razširjenih škodljivcev oljke. Večina varstvenih ukrepov temelji na insekticidih, predvsem na organskih fosforjevih estrih, piretroidih in nedavno uvedenem spinosadu. Insekticide se lahko nanese po celotni krošnji. Drugi, okolju prijaznejši način, vključuje uporabo insekticida $v$ kombinaciji $\mathrm{z}$ atraktanti in feromoni. Tak pripravek se lahko nanese na del krošnje in deluje kot zastrupljena vaba, ali pa se ga uporabi pri metodi masovnega lovljenja. Zaradi negativnih vplivov insekticidov na okolje se nenehno razvija nove metode varstva, s ciljem zmanjšati porabo insekticidov ali jih celo izločiti. Sem sodijo biološko varstvo $\mathrm{z}$ entomopatogeni organizmi, tehnika sterilnih insektov (SIT) ali transgena metoda RIDL (izpust insektov z dominantnimi letalnimi geni). Za doseganje učinkovite zaščite bi bilo omenjene alternativne metode potrebno izboljšati. Alternativne metode so nujne zaradi odpornosti na insekticide, ki se pojavi ob daljši uporabi insekticidov in zmanjšuje njihovo učinkovitost. V okviru članka je bil opravljen pregled molekularnih metod za spremljanje prisotnosti alelov, odgovornih za razvoj odpornosti na insekticide ter pregled stanja prisotnosti rezistentnih alelov v državah, kjer pridelujejo oljke.

Ključne besede: organski fosforjevi estri; ace gen; rezistentni aleli; metode varstva rastlin; alternativne metode; spinosad; biološko varstvo

1 Ph.D., University of Primorska, Faculty of Mathematics, Natural Sciences and Information Technologies, Glagoljaška 8, SI-6000 Koper, Slovenia; e-mail: matjaz.hladnik@upr.si 


\section{INTRODUCTION}

Olive fly (Bactrocera oleae (Rossi, 1790) Gmelin) is one of the most important olive pests worldwide (Daane and Johnson, 2010; Malheiro et al., 2015a). Until now, it has not been possible to find cultivars showing clear evidence of resistance or tolerance to this pest (Fabbri et al., 2009). However, not all olive cultivars are equally susceptible to olive fruit fly infestation. Some of the factors related to fruit traits that possibly play a role include fruit size and mass, color, fruit exocarp hardness, surface covering (mainly of aliphatic waxes), phenological stage of the crop, and chemical composition of olive fruits (Daane and Johnson, 2010; Malheiro et al., 2015a). Recently, Malheiro et al. (2016) studied olive fly oviposition preference to the volatiles from olive leaves from different cultivars and they observed correlation between infestation level during olive maturation and the aromatic hydrocarbon toluene. When volatiles from olive fruits were analysed, $\alpha$-copaene was found as an oviposition promoter (Malheiro et al., 2015b). Garantonakis et al. (2016) observed positive correlation between $B$. oleae infestation and the content of potassium and iron in olive fruits.
However, other factors with impact on olive fly population density have to be considered as well including weather conditions, location, a cultural landscape diversity, crop load, and agronomical technologies. It is known that the development of the olive fly is largely temperature dependent (Daane and Johnson, 2010; Podgornik et al., 2013). Ortega and Pascual (2014) detected a relationship between a population of $B$. oleae and landscape complexity that could occur through the presence of natural enemies of the phytophagous insects in some landscape elements, such as hedgerows or field margins adjacent to land uses with natural or rural vegetation. Regarding agronomical technologies, Burrack et al. (2008) observed more olive fruit flies captured in traps stationed in irrigated trees compared to unirrigated trees. Turning over the soil under the canopies is one of the preventive measures listed in International Olive Council (IOC) guidelines (Jardak et al., 2007) with the aim to disrupt the development of the pupal stage. However, such practice can have negative impacts on beneficial organisms (Herz et al., 2005) and causes soil erosion, loss of organic matter through mineralization, and nutrient leaching in underground water.

\section{PLANT PROTECTION AGAINST OLIVE FLY}

Since there are no other efficient methods to protect plants from the olive fly, common control methods against $B$. oleae remain insecticide-based. These are bait sprays, cover sprays, and mass trapping (Haniotakis, 2005). According to the IOC, a treatment threshold for cover sprays should be considered $(10 \%$ to $15 \%$ infested fruit intended for oil production and $1 \%$ to $2 \%$ for table olive production), while a poisoned bait should be used before or on the appearance of the first punctures (Jardak et al., 2007). Over the last four decades, organophosphate (OP) insecticides were the most frequently used. Recently, there has been an increased usage of pyrethroids, neonicotinoids, and very recently in a spinosad insecticide (Daane and Johnson, 2010; Knap and Bandelj, 2016; Varikou et al., 2016). Spinosad is available as a bite spray together with a foodstuff attractant in a product named GF-120 (Dow AgroSciences).
Bait sprays have an advantage over cover sprays, because they attract flies to the insecticide using an attractant. This minimizes the impact on natural enemies (Varikou et al., 2014) and reduces the total amount of pesticides used. Bait sprays are generally recognized to be an integral component of integrated pest management (Varikou et al., 2016). Nevertheless, it offers only limited success of protection. Bait sprays consist of hydrolyzed protein (serving as a bait) and of insecticide. In the past, many attempts were made to improve the attractiveness of bait spray solutions (Varikou et al., 2014; Varikou et al., 2015) and to develop new attract-and-kill traps (Potamitis et al., 2014; Yokoyama, 2014b). Varikou et al. (2014, 2015) observed reduced attractiveness in the attractant solution when plant protection products such as pyrethroids (lamba-cyhalothrin, alphacypermethrin) or organophosphorous (dimethoate) were added. The best results were obtained with a 
combination of all tested proteins and pyrethroids. The only exception was a mixture of Entomela 75 hydrolyzed protein and alpha-cypermethrin, while dimethoate and spinosad solutions displayed weaker attractiveness to $B$. oleae. Although Spinosad did not perform well in this study, its effectiveness is confirmed in large scale trials (Varikou et al., 2015).

Another disadvantage of attractants is their limited effective duration. Attractants do not seem to last more than three to six days in traps and more than three days in bait spray applications (Varikou et al., 2014). More recent results indicate that the ability of tested bait sprays to attract and kill is limited to the first day only with no significant capture observed after the second or third day (Varikou et al., 2015). More research is needed to formulate spraying solutions offering acceptable olive crop protection (Varikou et al., 2015). However, important observations toward reducing the quantity of insecticide in bait spray solutions were provided by Varikou et al. (2016). They observed that one-third or half of the recommended volume of spraying solution, which is $300 \mathrm{ml}$ per tree, was effective as well.

Other than residual bait activity time, other requirements for high efficacy of this method should be considered including area-wide application due to high mobility of adult flies and accurate timing so that the fruit infestation is avoided (Haniotakis, 2005). High mobility of olive flies was reported in a few field studies (Tzanakakis, 2003) and in population genetic analysis of $B$. oleae using microsatellite markers (Ochando and Reyes, 2000; Knap and Bandelj, 2016). In Greece, bait sprays are applied by tractors to almost all olive orchards and these applications are funded by the Hellenic Ministry of Rural Development and Food (Varikou et al., 2013).

Recently, a bait station for attraction and control of oriental fruit fly (Bactrocera dorsalis (Hendel, 1912)) was recently implemented (Piñero et al., 2010). Such attract-and-kill bait stations have the advantage over foliar applications, because the insecticidal bait is protected from weather conditions. Bait stations were tested for effectiveness against the olive fly as well
(Yokoyama, 2014a). The authors didn't confirm longer toxicity of insecticides due to protection of bait spray from weather (bait sprays and foliage applications were protected from rain in this study). The level of toxicity was lost after one week on bait stations and olive foliage. However, the major advantages of bait stations are that they are protected from rain and reduce the amount of bait spray used in olive orchard.

Traps are used for mass trapping or for olive fly monitoring with the aim to determine the appropriate time for treatments. Burrack et al. (2008) tested different traps (yellow sticky traps, ChamP traps and plastic McPhail traps) and different lures. Mcphail traps baited with torula yeast tablets were the most efficient. Results were confirmed by Varikou et al. (2013) when compared with yellow sticky panels and McPhail traps. Although the number of attracted flies in McPhails traps didn't provide a good estimation of the olive fly density, it was concluded that they can be accurate in determining the timing of spraying against $B$. oleae. McPhails traps are recommended in California. To monitor the olive fly population, Varikou et al. (2013, 2016) used McPhail glass traps with $2 \%$ ammonium sulphate which was replaced by $2 \%$ hydrolyzed protein (Entomela $75 \%$ ) at the end of August in the latest research. Traps based on proteins and other sources of ammonia primarily attract female flies because they require source of protein to ensure high fecundity (Hagen and Finney, 1950). Addition of pheromones didn't significantly increase olive fruit fly captures (Varikou et al., 2014). In Greek orchards ammonium salts are still used in McPhail traps during the whole period (summer and autumn), although it was proven that its attractiveness was significantly reduced compared to all tested protein hydrolysates (Haniotakis, 2005; Varikou et al., 2014). In Slovenia, the olive fly is monitored with yellow sticky traps with an added pheromone (Dacotrap $\AA$, Isagro S.p.a., Milan, Italy) (Knap and Bandelj, 2016). Rojnić et al. (2015) observed that McPhail traps with hydrolyzed protein were more attractive to olive flies than yellow sticky traps baited with a pheromone. However, the correlation coefficients that were calculated using the cumulative capture of olive flies were high, which proved the comparability of these two trap types. Disadvantages of McPhail traps are their lack of 
specificity in that they also attract non-target insects and are not efficient during periods of high humidity. However, since the information about female fecundity can be obtained by dissecting females caught in these traps, a combination of both McPhail traps and sex-pheromone baited traps gives the best population monitoring information (Bueno and Jones, 2002). Gil-Ortiz (2015) exposed the problem with biodegradability in commercial pheromone dispensers made of plastic polymers in which the pheromone is encapsulated and suggested the use of mesoporous materials as an ecological alternative. Some other target devices like plywood rectangles or bags dipped in insecticide, together with attractant and sex pheromone, were tested as well (Bueno and Jones, 2002).

Attempts were made with the aim to find out if there is a relation between captures in traps and infestation of olive fly, but no relation was observed (Varikou et al., 2016).

\subsection{Spinosad toxicity in comparison with other insecticides and its impact on beneficial organisms}

Akmoutsou et al. (2011) evaluated toxicity of spinosad and deltamethrin on B. oleae. Data showed that at the lowest concentrations of 0.05 $\mathrm{mg} \mathrm{l}^{-1}$ and $0.10 \mathrm{mg} \mathrm{l}^{-1}$, deltamethrin caused significantly higher mortality than spinosad, while at concentrations of $0.50 \mathrm{mg} \mathrm{l}^{-1}$ to $4.00 \mathrm{mg} \mathrm{l}^{-1}$ the lethal effects were similar. However, high mortality was observed after $72 \mathrm{~h}$ of exposure, suggesting a delayed lethal effect and that long periods of application may be needed for high mortality events to occur. Gonçalves et al. (2012) compared efficacy of spinosad and dimethoate in bait sprays and impact on non-target arthropods. Results suggested that spinosad could have the same effectiveness as dimethoate. Recently implemented studies of spinosad effect on nontargeted organisms revealed that it could be related to the meteorological conditions (Gonçalves et al., 2012), however, GF-120 indicated compatibility with the most important groups of natural enemies present in olive groves with the exception of Orius spp. and Aphelinidae (Pascual et al., 2014).

\subsection{Alternative methods for protection against olive fly}

As an alternative to commonly used insecticides, protection against olive fly with kaolin was suggested (Saour and Makee, 2004). However, a few studies reported that kaolin has a negative effect on the arthropod communities at soil level (Pascual et al., 2010; Bengochea et al., 2014).

An environmentally safe alternative to insect pest control is the sterile insect technique (SIT) (Zygouridis et al., 2014). This is a species-specific method of insect suppression in which insects are mass-reared under factory conditions, sterilized by irradiation, and then released (Leftwich et al., 2016). However, due to their adaptation to factory, laboratory, and irradiation, flies have significantly reduced fitness (Leftwich et al., 2016). Zygouridis et al. (2014) observed a substantial loss of variability between F1 and F2-F5 generations in the laboratory, while in F11 a complete adaptation to the new laboratory environment occurs. It was suggested that loss of variability is responsible for the loss of wild characters like low competitiveness of the sterile mass-reared males compared with the wild ones. Loss of variability was shown with microsatellite markers. Authors suggested a solution to refresh a mass-reared colony with wild material at about every five to eight generations (Zygouridis et al., 2014). Efforts to develop a vigorous and efficient mass-reared laboratory olive fly strain is underway. Additionally, a transgenic RIDL (release of insects carrying a dominant lethal) system is trying to overcome the limitations of SIT technology and the first transgenic strains for the olive fly were already developed (Ant et al., 2012; Genç et al., 2016).

Biological protection is the most sustainable method for the environment. A review of biological control attempts was made by Daane and Johnson (2010), concluding that biological control programs previously used did not consistently provide adequate levels of control across the range of climates and olive cultivars commercially grown. Between 2006 and 2013 a trial with a field release of specialized parasitoids, Psyttalia lounsburyi (Silvestri, 1913) and Psyttalia humilis (Silvestri, 1913), was conducted in California (Daane et al., 2015). However, they 
encountered inherent difficulties of establishing parasitoids in the field due to climatic extremes as well as because of periods with low host densities.

Effectiveness of soil applications beneath the tree canopy with entomopathogenic fungus Metarhizium brunneum Petch. EAMa 01/58-Su strain, perfectly adapted to Mediterranean soil conditions has been recently evaluated. Two applications were made per year from 2010 to 2015 , once in autumn to target larvae that exit from the fruits to the ground to pupate beneath the tree and spend the winter in the pupal stage and once in spring to target the emerging adults. A high reduction $(50 \%$ to $70 \%)$ in the $B$. oleae population emerging during the spring from the soil of treated plots was seen compared to controls plots. The authors marked it as efficient biological control method (Yousef et al., 2016).

With the aim to identify new natural enemies of the olive fly, a PCR-based diagnostic assay for detection of $B$. oleae in the gut of insects was developed (Rejili et al., 2016).

New control methods can be developed with new knowledge about microorganisms associated with the olive fly (Malacrinò et al., 2015). One example is the incompatible insect technique (IIT), which employs the cytoplasmic incompatibility (CI) induced by an insect symbiont such as Wolbachia (Apostolaki et al., 2011).

\section{IDENTIFICATION OF RESISTANCE ALLELS}

Since most control programmes against the olive fruit fly have been based on the use of insecticides like OPs, pyrethroids, and spinosad in the last few years, olive flies have developed resistance against them (Vontas et al., 2001; Haniotakis, 2005; Margaritopoulos et al., 2008; Kakani et al., 2010; Daane et al., 2015)). As observed by Kakani et al. (2010) in California where spinosad is the only registered phyto-pharmaceutical product, its exclusive use has led to greater levels of resistance. The intensity of the resistance was shown to be strongly correlated with local history of spinosad use. Five populations from California demonstrated a 9 to 13 -fold increase.

\subsection{Resistance to organophosphates}

One of the earlier studies of resistance to organophosphorus insecticides of $B$. oleae suggested that the resistance is based on increased expression of AChE (acetylcholinesterase) or a gene duplication (Tsakas, 1977). Vontas et al. (2001) showed with biochemical assays that modification of $\mathrm{AChE}$ is the dominant factor in organophosphate resistance in $B$. oleae (other metabolic pathways were not found to have major roles in resistance to OPs). AChE terminates nerve impulses by catalyzing the hydrolysis of the neurotransmitter acetylcholine. It is a key enzyme in the insect nervous system (Mutero et al., 1994). Comparison of the cDNA sequences of $B$. oleae which encode AChE in susceptible and organophosphate resistant $B$. oleae revealed two polymorphisms, resulting in amino acid substitution (I214V and G488S) in the insecticide resistant strains. A combination of $\mathrm{I} 214 \mathrm{~V}$ and S488G was found in all samples. A field population collected from Attiki, Greece, possessing both mutations, exhibit 16-fold AChE insensitivity compared to susceptible $B$. oleae (Vontas et al., 2002). There were some examples, when mutation $214 \mathrm{~V}$ was found in the absence of 488S (Hawkes et al., 2005; Nardi et al., 2006). On the contrary, the mutation G488S is almost always accompanied by I214V (Hawkes et al., 2005). Pereira-Castro et al. (2015) observed all samples from Iberia to have both mutations in the same chromosome.

When ace (gene for $\mathrm{AChE}$ ) locus was sequenced by Kakani et al. (2008), a new mutation was discovered, 9 bp deletion (termed $\Delta 3 \mathrm{Q}$ ) in exon $\mathrm{X}$, which showed a strong correlation with OPresistance levels. They analyzed olive flies which were previously used by Skouras et al. (2007) in an insecticide assay to study the resistance to dimethoate in B. oleae populations from Greece, its islands, and Cyprus. Populations from Crete showed the highest resistance ratio values from 30 to 64 (calculated as a ratio of median effective dose $\left(\mathrm{ED}_{50}\right)$ of each tested population and $\mathrm{ED}_{50}$ of the laboratory susceptible strain), while on Cyprus all populations showed low resistance levels (resistance ratio less than 10). The mutation 
resulted in a deletion of three glutamine residues at positions 642-644. Since it was always found as a heterozygous, the authors suggested higher fitness costs of $\triangle 3 \mathrm{Q}$ mutation. They suggested that $\mathrm{I} 214 \mathrm{~V}$ and G488S are the first ones to be selected under the minimum OP pressure, while $\triangle 3 \mathrm{Q}$ appears to be associated with resistance at higher OP doses. $\triangle 3 \mathrm{Q}$ is located outside the catalytic center of the enzyme and it is suggested that it affects the glycosylphosphatidylinisotol-anchoring efficiency or the stability of the protein. A more detailed account of the role of $\Delta 3 \mathrm{Q}$ and two other mutations were discussed by Kakani and Mathiopoulos (2008) and Kakani et al. (2011).

Pereira-Castro et al. (2015) identified a new mutation that causes an alanine to valine substitution at residue 298 (A298V). However, a functional role has not yet been solved.

\subsection{Resistance to other insecticides}

Regarding the resistance to alpha-cypermethrin, it was indicated that cytochrome P450 monooxygenase could be involved in a resistance mechanism. While no correlation between enzyme activity and resistance was found with carboxylesterase (COE) and glutathione-Stransferase (GST), as well as genetic polymorphism of domain IIS4-IIS6 of the B. oleae para-type sodium channel could not be responsible for resistance (Margaritopoulos et al., 2008).

Resistance to insecticides has been studied with NGS technologies as well. A whole transcriptome analysis of spinosad susceptible and resistant flies indicated that several immune system loci as well as elevated energy requirements of the resistant flies might be necessary to lever the detoxification process (Efthimia et al., 2014).

Pavlidi et al. (2013) studied B. oleae mRNA and identified at least 132 putative major detoxification genes involved in the metabolism of xenobiotics, such as plant phytotoxins and insecticides.

\section{MOLECULAR METHODS FOR MONITORING THE RESISTANCE ALLELES TO OPS}

With the aim to easily detect the presence of I214V in exon III (assigned to exon IV by Kakani and Mathiopoulos (2008)) and G488S in exon VI (assigned to exon VII), a simple PCR-RFLP assay was developed (Hawkes et al., 2005). Detection of $\mathrm{I} 214 \mathrm{~V}$ is based on the fact that $\mathrm{I} 214 \mathrm{~V}$ mutation creates a site for the restriction enzyme AccI, while detection of G488S is based on associated neutral polymorphism, which destroys a site for Bss HII (sequence conservation and the correlation between the two $G$ to $A$ transitions should be confirmed by sequencing of alleles in any studies). Primers Boace3F and Boace3R were designed for amplification of 232 bp fragment within exon III, while Boace6F and Boace6R amplify 106 bp product within exon VI. The presence of resistant alleles is identified with AccI digested two fragments (168 bp and $64 \mathrm{bp}$ ) and the presence of full-length (106 bp) resistance-associated exon VI alleles. Susceptible alleles (G488) give bands of 50 and $56 \mathrm{bp}$.
Nardi et al. (2006) developed primers to amplify two regions that nearly completely include exons III and VI that carry the two mentioned mutations: BoAce_518F and BoAce_1040R; BoAce_1424F and BoAce_1519R, respectively. After primer removal the amplified fragments correspond to $521 \mathrm{bp}$ of $543 \mathrm{bp}$ in exon III and $94 \mathrm{bp}$ of putative $150 \mathrm{bp}$ in exon VI. After PCR reaction, both strands were sequenced and sequences showing double peaks were recorded as heterozygotes and subjected to cloning to resolve and differentiate the two alleles.

Margaritopoulos et al. (2008) developed a new PCR-RFLP diagnostic assay for G488S mutation. The method, previously developed by Hawkes et al. (2005) is based on G488S associated neutral polymorphism, but according to sequences of allele $\mathrm{d}$ and $\mathrm{f}$, which were obtained by Nardi et al. (2006), this two mutations are not always present together. Newly developed primers (D6F, D6R) directly target the resistance mutation G448S. A reverse primer, D6R, has been designed to 
introduce a base substitution into $100 \mathrm{bp}$ PCR product, which in combination with the resistant allele generates a recognition site for MbiI. Digested PCR product results in two fragment, $31 \mathrm{bp}$ and $69 \mathrm{bp}$ in length.

Kakani et al. (2008) aimed to analyze the nucleotide sequence of the ace locus in order to isolate additional mutations and therefore developed five primer pairs for amplification of exons II, III-IV (includes introns), VIII, IX, and X. Forward primer for exons III-IV is labeled as Boace $3 \mathrm{~F}$, which is the same as the primer developed by Hawkes et al. (2005) but with different sequence, so a caution has to be taken when using this primer. Boace10F and Boace10R primers were used for detection of $\triangle 3 \mathrm{Q}$ mutation. PCR of the wild type allele yields a $96 \mathrm{bp}$ product whereas PCR of the mutant allele yields an $87 \mathrm{bp}$ product.

Kakani et al. (2013) developed PCR-RFLP, allelespecific, and Taq-Man assay methods for the identification of $\triangle 3 Q$ mutation. In the first method, Boace $10 \mathrm{~F}$ and Boace10R primers were used for the amplification of exon X. PCR product of the wild allele, $96 \mathrm{bp}$ in length, is digested with $M w o$ I enzyme, and results in two fragments, $59 \mathrm{bp}$ and $37 \mathrm{bp}$. PCR product of the mutant allele, $87 \mathrm{bp}$ in length, remains undigested because the $\Delta 3 \mathrm{Q}$ mutation affects restriction site. Digestion enables detection of genotype on a gel with lower resolution compared to undigested fragments. An allele specific method is done with primers Ex10wt3'F-IMP and Boace10R (to test the presence of the wild type allele, $76 \mathrm{bp}$ fragment) or with primers Ex10mut3'F-IMP and Boace10R (to test the presence of the mutant $\triangle 3 \mathrm{Q}$ allele, $67 \mathrm{bp}$ fragment). The two Ex10 primers are identical except for the last 3' base that provides the specificity for one or the other allele and introduces internal mismatch in order to increase the specificity. For the detection of $\mathrm{I} 214 \mathrm{~V}$ and G488S mutations a new duplex qPCR assay was developed.

Pereira-Castro et al. (2015) developed new primers for amplification of different segments of the ace gene to achieve a more complete analysis of haplotypes associated with OP-resistance and OPsensitive ace alleles (primers were named Bo12 or Bo14 followed by a dash and a number).

\section{FREQUENCY OF RESISTANT ALLELES TO OP ON THE FIELD}

\subsection{Frequency of $\mathrm{I} 214 \mathrm{~V}$ and G448S}

Hawkes et al. (2005) analyzed samples from Greece, Albania, Italy, France, Spain, and South Africa for the presence of I214V and G488S. 488S was detected in all samples from Greece, almost all field samples from Albania, while high levels were observed in two Italian locations and at lower frequencies in France and Spain. The majority of these $488 \mathrm{~S}$ individuals also carried $214 \mathrm{~V}$. Double mutation haplotype is lower in western Mediterranean regions, which was attributed to lower usage of OPs. Samples from South Africa were homozygous for wild-type for both alterations.

Results of Hawkes et al. (2005) were confirmed by Nardi et al. (2006) where olive flies from Pakistan, Africa, Mediterranean countries, the Middle East, and America were analyzed. No resistant alleles were identified in Pakistan and African samples, low to moderate $(50 \%)$ frequency was observed in the Middle East and America samples, while the highest proportion of resistance alleles was observed in the Mediterranean area, where frequencies approach $100 \%$ in Greece and (central/southern) Italy. However, in France and Portugal the frequency of resistance alleles was below $30 \%$ and $0 \%$, respectively. Nardi et al. (2006) identified $3.4 \%$ samples of chromosomes carrying only I214V (previously identified by Hawkes et al. (2005) in only one French sample). Interestingly, two alleles carrying the mutation I214V were identified (named A and W) which differ by 6 synonymous substitutions. Allele W was found on the island of Sicily, whereas resistant allele A was present at high frequency throughout Greece and south/central Italy. It was suggested that two independent acquisitions of this mutation occurred. Assuming that the mutation most likely happened in an area where the precursor alleles are present, authors hypothesized that allele A arose in the Middle East (the same is suggested for the allele carrying mutation G488S). The high frequency and broad geographic distribution of 
allele A compared to that of allele W, would suggest that allele $\mathrm{A}$ is older.

Pereira-Castro et al. (2015) analyzed olive flies from the Iberian Peninsula (Portugal and Spain) and both I214V and G488S mutations were found at medium to high frequencies in all locations, demonstrating they are now widespread even in Portugal, while in Andalusia their frequencies vary widely, from $20 \%$ to $90 \%$. Since complete concordance between the zygosities of I214V and G488S was observed, authors suggested that the chromosome carrying both substitutions was introduced.

Doğaç et al. (2015) studied olive flies collected in 2010 from 12 provinces from Aegean and Mediterranean regions in Turkey and found that resistant forms of exon III and VI had a low to moderate frequency, while they reached the highest frequency, nearly $80 \%$, in the Aegean populations. This indicates that they were selected in the Aegean coast of Turkey and then spread westward towards Europe. Aegean populations showed a more limited variability of exon III and VI as well.

Hanife (2016) analyzed flies from Çanakkale province, Turkey, for the presence of G488S mutation. Olives sampled in 2006 showed $31.7 \%$ resistant allele homozygosity, $54.14 \%$ were homozygous in 2007, while in 2013, $81.77 \%$ of homozygous flies were observed. Only $3.10 \%$ and $1.10 \%$ of susceptible flies were observed in 2006 and 2007, respectively, while no susceptible flies were identified in 2013. Resistance development is evident in the field as well, since many local farmers complained about inefficiency of their applications.

\subsection{Frequency of $\Delta 3 Q$ mutation}

The analysis of $\triangle 3 \mathrm{Q}$ mutation distribution in the Mediterranean (Israel, France, Cyprus, Greece, Italy, Spain, Portugal and Marocco) revealed the highest frequencies, $12.5 \%$ and $11.1 \%$ found in Greece and Italy, respectively, whereas a gradual decrease of $\triangle 3 \mathrm{Q}$ frequency towards the western Mediterranean was also noted. In Portugal no resistant allele was found (Kakani et al., 2013). Results are consistent with the distribution of the other two resistance associated point mutations (Hawkes et al., 2005; Nardi et al., 2006). The absence of $\triangle 3 \mathrm{Q}$ in Portugal was confirmed recently by Pereira-Castro et al. (2015). However, they didn't observed $\triangle 3 \mathrm{Q}$ mutation in Spain, but Kakani et al. (2013) detected one allele with $\Delta 3 \mathrm{Q}$ mutation.

Doğaç et al. (2015) monitored the presence of $\Delta 3 \mathrm{Q}$ mutation in the Mediterranean and Aegean regions of Turkey. They observed $\triangle 3 \mathrm{Q}$ mutation to be more widespread in the Mediterranean region with frequencies from $6 \%$ to $20 \%$. In the Aegean region with greater insecticide pressure, lower frequencies of $\triangle 3 \mathrm{Q}$ were observed (from $2 \%$ to $8 \%$, while in some locations it was not even detected). All previous observations of several authors identified $\triangle 3 \mathrm{Q}$ to be always in a heterozygous state. However, Doğaç et al. (2015) identified one homozygous sample in the Hatay and one in the Aydin populations.

\section{CONCLUSIONS}

Genetic studies revealed that OPs resistance loci (I214V, G488S) are now present in all European Mediterranean countries. The first studies suggested (Hawkes et al., 2005; Nardi et al., 2006) that selection caused by insecticide had the greatest impact on the resistance loci expansion, while some other evolutionary forces were suggested as well. However, since both mutations are now widespread in Portugal and Spain with frequencies above $80 \%$, it could be suggested that new alleles were in the process of introduction in the last few decades. This hypothesis is supported by Pereira-
Castro et al. (2015) who found a great difference in resistant associated allele frequencies between locations, only few kilometers apart. The differences were attributed to recent introduction of resistant alleles. However, differences in frequencies of resistant associated alleles were found in Turkey as well (Doğaç et al., 2015), possibly due to local specificity of insecticides use. Another interesting finding was observed by the same authors who identified higher frequency of $\triangle 3 \mathrm{Q}$ mutation in a region with lower frequencies of the other two mutations. They explained this 
phenomenon with greater fitness disadvantage compared with that of the other two point mutations ( $\triangle 3 \mathrm{Q}$ offers resistance to only some insecticides pressure). Genetic and biochemical studies showed that high levels of resistance to insecticides from different classes have been developed. In order to reduce the amount of insecticide used in the future and to prevent the development of resistance, further research work on efficient plant protection methods should be continued.

\section{REFERENCES}

Akmoutsou, P., Mademtzoglou, D., Nakou, I., Onoufriadis, A., Papadopoulou, X., Kounatidis, I., Mavragani-Tsipidou, P. (2011). Evaluation of toxicity and genotoxic effects of spinosad and deltamethrin in Drosophila melanogaster and Bactrocera oleae. Pest Management Science, 67(12), 1534-1540. doi:10.1002/ps.2208

Ant, T., Koukidou, M., Rempoulakis, P., Gong, H.-F., Economopoulos, A., Vontas, J., Alphey, L. (2012). Control of the olive fruit fly using geneticsenhanced sterile insect technique. BMC Biology, 10(1), 1-8. doi:10.1186/1741-7007-10-51

Apostolaki, A., Livadaras, I., Saridaki, A., Chrysargyris, A., Savakis, C., Bourtzis, K. (2011). Transinfection of the olive fruit fly Bactrocera oleae with Wolbachia: towards a symbiont-based population control strategy. Journal of Applied Entomology, 135(7), 546-553. doi:10.1111/j.14390418.2011.01614.x

Bengochea, P., Budia, F., Viñuela, E., Medina, P. (2014). Are kaolin and copper treatments safe to the olive fruit fly parasitoid Psyttalia concolor? Journal of Pest Science, 87(2), 351-359. doi:10.1007/s10340-013-0543-5

Bueno, A. M., Jones, O. (2002). Alternative methods for controlling the olive fly, Bactrocera oleae, involving semiochemicals. IOBC wprs Bulletin, 25(9), 147-156.

Burrack, H. J., Connell, J. H., Zalom, F. G. (2008). Comparison of olive fruit fly (Bactrocera oleae (Gmelin)) (Diptera: Tephritidae) captures in several commercial traps in California. International Journal of Pest Management, 54(3), 227-234. doi:10.1080/09670870801975174

Daane, K. M., Johnson, M. W. (2010). Olive Fruit Fly: Managing an Ancient Pest in Modern Times. Annual review of entomology, 55(1), 151-169. doi:10.1146/annurev.ento.54.110807.090553

Daane, K. M., Wang, X., Nieto, D. J., Pickett, C. H., Hoelmer, K. A., Blanchet, A., Johnson, M. W. (2015). Classic biological control of olive fruit fly in California, USA: release and recovery of introduced parasitoids. BioControl, 60(3), 317-330. doi:10.1007/s10526-015-9652-9

Doğaç, E., Kandemir, İ., Taşkın, V. (2015). Geographical distribution and frequencies of organophosphate-resistant Ace alleles and morphometric variations in olive fruit fly populations. Pest Management Science, 71(11), 1529-1539. doi:10.1002/ps.3958

Efthimia, S., Martin, R., Maria-Eleni, G., Konstantina T, T., Nikolaos E, Z., Klelia D, S., Kostas D, M. (2014). Olive fly transcriptomics analysis implicates energy metabolism genes in spinosad resistance. 15, 714. doi:10.1186/1471-2164-15-714

Fabbri, A., Lambardi, M., Ozden-Tokatli, Y. (2009). Olive Breeding. In S. M. Jain \& P. M. Priyadarshan (Eds.), Breeding Plantation Tree Crops: Tropical Species (pp. 423-465). New York, NY: Springer New York. doi:10.1007/978-0-387-71201-7_12

Garantonakis, N., Varikou, K., Markakis, E., Birouraki, A., Sergentani, C., Psarras, G., Koubouris, G. C. (2016). Interaction between Bactrocera oleae (Diptera: Tephritidae) infestation and fruit mineral element content in Olea europaea (Lamiales: Oleaceae) cultivars of global interest. Applied Entomology and Zoology, 51(2), 257-265. doi:10.1007/s13355-016-0397-4

Genç, H., Schetelig, M. F., Nirmala, X., Handler, A. M. (2016). Germline transformation of the olive fruit fly, Bactrocera oleae (Rossi) (Diptera: Tephritidae), with a piggyBac transposon vector. Turkish Journal of Biology, 40(4), 845-855. doi:10.3906/biy-1510-55

Gil-Ortiz, R. (2015). Development of new ecological long-lasting dispensers of semiochemicals for the control of Bactrocera oleae (Rossi). Pest Management Science, 71(12), 1694-1694. doi:10.1002/ps.4156

Gonçalves, M. F., Santos, S. A. P., Torres, L. M. (2012). Efficacy of spinosad bait sprays to control Bactrocera oleae and impact on non-target arthropods. Phytoparasitica, 40(1), 17-28. doi:10.1007/s12600-011-0195-z 
Hagen, K. S., Finney, G. L. (1950). A Food Supplement for Effectively Increasing the Fecundity of Certain Tephritid Species. Journal of Economic Entomology, 43(5), 735. doi:10.1093/jee/43.5.735

Hanife, G. (2016). Screening of Organophosphate Resistance in the Acetycholinesterase Gene of Field Collected Olive Fruit Fly, Bactrocera Oleae Rossi (Diptera: Tephritidae). Romanian Biotechnological Letters, 21(1), 11209-11216.

Haniotakis, G. E. (2005). Olive pest control: present status and prospects. Bulletin OILB/SROP, 28(9), 19.

Hawkes, N. J., Janes, R. W., Hemingway, J., Vontas, J. (2005). Detection of resistance-associated point mutations of organophosphate-insensitive acetylcholinesterase in the olive fruit fly, Bactrocera oleae (Gmelin). Pesticide Biochemistry and Physiology, 81(3), 154-163. doi:10.1016/j.pestbp.2004.11.003

Herz, A., Hassan, S. A., Hegazi, E., Nasr, F. N., Youssef, A. A., Khafagi, W. E., Pereira, J. A. (2005). Towards sustainable control of Lepidopterous pests in olive cultivation. Gesunde Pflanzen, 57(5), 117-128. doi:10.1007/s10343-0050076-9

Jardak, T., Ali Triki, M., Rhouma, A., Ksantini, M. (2007). Plant health protection. Production techniques in olive growing. Madrid, MD: International Olive Council.

Kakani, E. G., Bon, S., Massoulié, J., Mathiopoulos, K. D. (2011). Altered GPI modification of insect AChE improves tolerance to organophosphate insecticides. Insect Biochemistry and Molecular Biology, 41(3), 150-158. doi:10.1016/j.ibmb.2010.11.005

Kakani, E. G., Ioannides, I. M., Margaritopoulos, J. T., Seraphides, N. A., Skouras, P. J., Tsitsipis, J. A., Mathiopoulos, K. D. (2008). A small deletion in the olive fly acetylcholinesterase gene associated with high levels of organophosphate resistance. Insect Biochemistry and Molecular Biology, 38(8), 781787. doi:10.1016/j.ibmb.2008.05.004

Kakani, E. G., Mathiopoulos, K. D. (2008). Organophosphosphate resistance-related mutations in the acetylcholinesterase gene of Tephritidae. Journal of Applied Entomology, 132(9-10), 762771. doi:10.1111/j.1439-0418.2008.01373.x

Kakani, E. G., Sagri, E., Omirou, M., Ioannides, I. M., Mathiopoulos, K. D. (2013). Detection and geographical distribution of the organophosphate resistance-associated $\Delta 3$ Qace mutation in the olive fruit fly, Bactrocera oleae (Rossi). Pest
Management $\quad$ Science, 70(5), 743-750. doi:10.1002/ps.3564

Kakani, E. G., Zygouridis, N. E., Tsoumani, K. T., Seraphides, N., Zalom, F. G., Mathiopoulos, K. D. (2010). Spinosad resistance development in wild olive fruit fly Bactrocera oleae (Diptera: Tephritidae) populations in California. Pest Management Science, 66(4), 447-453. doi:10.1002/ps.1921

Knap, T., Bandelj, D. (2016). Microsatellite analysis revealed a different approach of control of olive fly population (Bactrocera oleae) in Slovenia. Journal of Applied Entomology. doi:10.1111/jen.12333

Leftwich, P. T., Bolton, M., Chapman, T. (2016). Evolutionary biology and genetic techniques for insect control. Evolutionary Applications, 9(1), 212-230. doi:10.1111/eva.12280

Malacrinò, A., Schena, L., Campolo, O., Laudani, F., Palmeri, V. (2015). Molecular analysis of the fungal microbiome associated with the olive fruit fly Bactrocera oleae. Fungal Ecology, 18, 67-74. doi:10.1016/j.funeco.2015.08.006

Malheiro, R., Casal, S., Baptista, P., Pereira, J. A. (2015a). A review of Bactrocera oleae (Rossi) impact in olive products: From the tree to the table. Trends in Food Science \& Technology, 44(2), 226242. doi:10.1016/j.tifs.2015.04.009

Malheiro, R., Casal, S., Cunha, S. C., Baptista, P., Pereira, J. A. (2015b). Olive Volatiles from Portuguese Cultivars Cobrançosa, Madural and Verdeal Transmontana: Role in Oviposition Preference of Bactrocera oleae (Rossi) (Diptera: Tephritidae). PLoS ONE, 10(5), e0125070. doi:10.1371/journal.pone.0125070

Malheiro, R., Casal, S., Cunha, S. C., Baptista, P., Pereira, J. A. (2016). Identification of leaf volatiles from olive (Olea europaea) and their possible role in the ovipositional preferences of olive fly, Bactrocera oleae (Rossi) (Diptera: Tephritidae). Phytochemistry, 121, 11-19. doi:10.1016/j.phytochem.2015.10.005

Margaritopoulos, J. T., Skavdis, G., Kalogiannis, N., Nikou, D., Morou, E., Skouras, P. J., Vontas, J. (2008). Efficacy of the pyrethroid alphacypermethrin against Bactrocera oleae populations from Greece, and improved diagnostic for an iAChE mutation. Pest Management Science, 64(9), 900-908. doi:10.1002/ps. 1580

Mutero, A., Pralavorio, M., Bride, J. M., Fournier, D. (1994). Resistance-associated point mutations in insecticide-insensitive acetylcholinesterase. Proceedings of the National Academy of Sciences 
of the United States of America, 91(13), 5922-5926. doi:10.1073/pnas.91.13.5922

Nardi, F., Carapelli, A., Vontas, J. G., Dallai, R., Roderick, G. K., Frati, F. (2006). Geographical distribution and evolutionary history of organophosphate-resistant Ace alleles in the olive fly (Bactrocera oleae). Insect Biochemistry and Molecular Biology, 36(7), 593-602. doi:10.1016/j.ibmb.2006.05.002

Ochando, M. D., Reyes, A. (2000). Genetic population structure in olive fly Bactrocera oleae (Gmelin): gene flow and patterns of geographic differentiation. Journal of Applied Entomology, 124(3-4), 177-183. doi:10.1046/j.14390418.2000.00460.x

Ortega, M., Pascual, S. (2014). Spatio-temporal analysis of the relationship between landscape structure and the olive fruit fly Bactrocera oleae (Diptera: Tephritidae). Agricultural and Forest Entomology, 16(1), 14-23. doi:10.1111/afe.12030

Pascual, S., Cobos, G., Seris, E., González-Núñez, M. (2010). Effects of processed kaolin on pests and non-target arthropods in a Spanish olive grove. Journal of Pest Science, 83(2), 121-133. doi:10.1007/s10340-009-0278-5

Pascual, S., Cobos, G., Seris, E., Sánchez-Ramos, I., González-Núñez, M. (2014). Spinosad bait sprays against the olive fruit fly (Bactrocera oleae (Rossi)): effect on the canopy non-target arthropod fauna. International Journal of Pest Management, 60(4), 258-268. doi:10.1080/09670874.2014.966171

Pavlidi, N., Dermauw, W., Rombauts, S., Chrisargiris, A., Van Leeuwen, T., Vontas, J. (2013). Analysis of the Olive Fruit Fly Bactrocera oleae Transcriptome and Phylogenetic Classification of the Major Detoxification Gene Families. PLoS ONE, 8(6), e66533. doi:10.1371/journal.pone.0066533

Pereira-Castro, I., Van Asch, B., Trindade Rei, F., Teixeira da Costa, L. (2015). Bactrocera oleae (Diptera: Tephritidae) organophosphate resistance alleles in Iberia: Recent expansion and variable frequencies. European Journal of Entomology, 112(1), 20-26. doi:10.14411/eje.2015.019

Piñero, J. C., Mau, R. F. L., Vargas, R. I. (2010). Comparison of Rain-Fast Bait Stations Versus Foliar Bait Sprays for Control of Oriental Fruit Fly, Bactrocera dorsalis, in Papaya Orchards in Hawaii. Journal of Insect Science, 10, 157. doi:10.1673/031.010.14117

Podgornik, M., Vuk, I., Arbeiter, A., Hladnik, M., Bandelj, D. (2013). Population Fluctuation of Adult
Males of the Olive Fruit Fly Bactrocera oleae (Rossi) Analysis in Olive Orchards in Relation to Abiotic Factors. Entomological News, 123(1), 1525. doi:10.3157/021.123.0106

Potamitis, I., Rigakis, I., Fysarakis, K. (2014). The Electronic McPhail Trap. Sensors, 14(12), 2228522299. doi:10.3390/s141222285

Rejili, M., Fernandes, T., Dinis, A. M., Pereira, J. A., Baptista, P., Santos, S. A. P., Lino-Neto, T. (2016). A PCR-based diagnostic assay for detecting DNA of the olive fruit fly, Bactrocera oleae, in the gut of soil-living arthropods. Bulletin of Entomological Research, 106(5), 695-699. doi:10.1017/S000748531600050X

Rojnić, I. D., Bažok, R., Barčić, J. I. (2015). Reduction of olive fruit fly damage by early harvesting and impact on oil quality parameters. European Journal of Lipid Science and Technology, 117(1), 103-111. doi:10.1002/ej1t.201400150

Saour, G., Makee, H. (2004). A kaolin-based particle film for suppression of the olive fruit fly Bactrocera oleae Gmelin (Dip., Tephritidae) in olive groves. Journal of Applied Entomology, $128(1), \quad 28-31 . \quad$ doi:10.1046/j.14390418.2003.00803.x

Skouras, P. J., Margaritopoulos, J. T., Seraphides, N. A., Ioannides, I. M., Kakani, E. G., Mathiopoulos, K. D., Tsitsipis, J. A. (2007). Organophosphate resistance in olive fruit fly, Bactrocera oleae, populations in Greece and Cyprus. Pest Management Science, 63(1), 42-48. doi:10.1002/ps.1306

Tsakas, S. C. (1977). Genetics of Dacus oleae. VIII. Selection for the Amount of Acetylcholinesterase after Organophosphate Treatment. Evolution, 31(4), 901-904. doi:10.2307/2407454

Tzanakakis, M. E. (2003). Seasonal development and dormancy of insects and mites feeding on olive: A review. Netherlands Journal of Zoology, 52(2), 87224. doi:10.1163/156854203764817670

Varikou, K., Alexandrakis, V., Gika, V., Birouraki, A., Marnelakis, C., Sergentani, C. (2013). Estimation of fly population density of Bactrocera oleae in olive groves of Crete. Phytoparasitica, 41(1), 105111. doi: $10.1007 / \mathrm{s} 12600-012-0270-0$

Varikou, K., Garantonakis, N., Birouraki, A. (2014). Response of olive fruit fly Bactrocera oleae to various attractant combinations, in orchards of Crete. Bulletin of Insectology, 67(1), 109-114.

Varikou, K., Garantonakis, N., Birouraki, A. (2015). Residual attractiveness of various bait spray 
solutions to Bactrocera oleae. Crop Protection, 68, 60-66. doi:10.1016/j.cropro.2014.11.009

Varikou, K., Garantonakis, N., Birouraki, A., Ioannou, A., Kapogia, E. (2016). Improvement of bait sprays for the control of Bactrocera oleae (Diptera: Tephritidae). Crop Protection, 81, 1-8. doi:10.1016/j.cropro.2015.11.007

Vontas, J. G., Cosmidis, N., Loukas, M., Tsakas, S., Hejazi, M. J., Ayoutanti, A., Hemingway, J. (2001). Altered Acetylcholinesterase Confers Organophosphate Resistance in the Olive Fruit Fly Bactrocera oleae. Pesticide Biochemistry and Physiology, 71(2), 124-132. doi:10.1006/pest.2001.2568

Vontas, J. G., Hejazi, M. J., Hawkes, N. J., Cosmidis, N., Loukas, M., Hemingway, J. (2002). Resistanceassociated point mutations of organophosphate insensitive acetylcholinesterase, in the olive fruit fly Bactrocera oleae. Insect Molecular Biology, 11(4), 329-336. doi:10.1046/j.13652583.2002.00343.x
Yokoyama, V. Y. (2014a). Olive fruit fly adult response to attract-and-kill bait stations in greenhouse cages with weathered bait spray and a commercial table olive orchard. Journal of Asia-Pacific Entomology, 17(4), 717-721. doi:10.1016/j.aspen.2014.07.004

Yokoyama, V. Y. (2014b). Response of Olive Fruit Fly (Diptera: Tephritidae) to an Attract-and-Kill Trap in Greenhouse Cage Tests. 14(250). doi:10.1093/jisesa/ieu112

Yousef, M., Garrido-Jurado, I., Ruíz-Torres, M., Quesada-Moraga, E. (2016). Reduction of adult olive fruit fly populations by targeting preimaginals in the soil with the entomopathogenic fungus Metarhizium brunneum. Journal of Pest Science, 110. doi:10.1007/s10340-016-0779-y

Zygouridis, N. E., Argov, Y., Nemny-Lavy, E., Augustinos, A. A., Nestel, D., Mathiopoulos, K. D. (2014). Genetic changes during laboratory domestication of an olive fly SIT strain. Journal of Applied Entomology, 138(6), 423-432. doi:10.1111/jen.12042 